\title{
Schools as Mediatized Worlds from a Cross-cultural Perspective
}

Andreas Breiter

\section{Introduction}

If we think about education in the $21^{\text {st }}$ century, we can identify a process of continuous change that is happening globally. Schools, in particular, are under constant reform pressure from the Education Reform Act in the UK (1988), "No Child Left Behind" in the U.S. (2001) to Post-PISA in Germany. Furthermore, these processes are intertwined with meta-processes such as mediatization, globalization or commercialization. In order to understand the transformation of education, we need to understand the complex interplay between organizational reform (devolution, school autonomy and accountability) and changing media and its role for communication. The first is mainly induced by political pressure on the macro level as well as on the micro level by parents. The second influences and is influenced by the way, how children learn and teachers teach, i.e. communicate - inside and outside the classroom - and how administrators manage a school on the meso level. Hence, the traditional perspective of the functional distinction between the three levels of educational governance (Altrichter, Brüsemeister, \& Wissinger, 2007) underestimates the process perspective across the levels, which is described by the meta-process of "mediatization" (e.g. Krotz, 2007, 2009; Hepp, 2012b; Lundby, 2009 or Hjarvard 2012).

Educational reform in the process of mediatization can be framed by looking at schools as "mediatized worlds". ${ }^{1}$ With this, patterns of transformation in the "communicative construction" (Putnam, \& Nicotera 2010) of the school as an organization can be linked to the "moulding forces of the media" (Hepp, 2012a). Furthermore, the combination of the threelevel model of educational governance and the process perspective of mediatization can help

1 The research was funded by Deutsche Forschungsgemeinschaft in the Priority Program 1505 "Mediatized Worlds" (Funding number: BR 2273/10-1). 
to understand cross-cultural differences in educational reform and development with the example of the UK and Germany.

\section{Schools as Mediatized Worlds}

Similar to individualization, globalization and commercialization, the process of mediatization has been described by Krotz as a meta-process, (Krotz, 2007, 2009). This longterm perspective of continuous change is strongly connected to emerging media and the process of institutionalization. Similar to Moores (2012), Krotz follows a non-media-centric perspective in order to describe social phenomena. Furthermore, "new" media do not replace “older" media but rather co-exist and merge, as somewhat "moulding forces" (Hepp, 2012a). As the concept of mediatization is based on communication as the basic principle of how people construct the social and cultural world, this can be used to understand different "social worlds". Building on Shibutani's (1955) understanding, social worlds can be framed as being continuously communicatively reconstructed. For Shibutani, each social world "is a culture area, the boundaries of which are set neither by territory nor by formal group membership but by limits of effective communication" (Shibutani, 1955, p. 566). Education can be regarded as an example of a social world, taking into account that this social world represents the core mechanism through which values and relations are passed on from one to the next generation (Bourdieu \& Passeron, 1977). It can be defined and measured in different forms in relation to individuals (the educated self based on knowledge and dispositions to learn and to value education), objects (such as books, degrees or computers) and institutions (such as libraries, schools or universities). Hence, we can observe a change of social worlds as they rely heavily on communicative practices. Given this, mediatization can help us to understand the complex transformation processes in education, and in schools in particular as the dominant form of institutionalized education. As digital media technologies become more and more available and communicative processes change, schools can be framed as mediatized worlds. 
Education has been subject to intensive research about the changes in teaching and learning, but most of the studies focus on student outcomes. Many empirical studies in schools all over the world show ambivalent results with regard to learning outcomes, student motivation or media literacy (e.g. Kozma, 2003; Pelgrum, 2001). But only limited research can be found examining the increasing relevance of digital media in communicative processes within the school as a social organization. The use of school information systems', educational data warehouses and learning management systems become a natural element of school-wide internal communication. Empirical research suggests (e.g. Breiter, Welling, \& Schulz, 2011; Visscher et al., 2003) that different media are used for different purposes (announcements, information distribution, exchange of teaching material etc.) and with different stakeholders (teachers, students, administrators, parents). As Selwyn (2011) noticed, the managerial core of the school and the governance structure of the school system has a major influence in the way digital media are used and, hence, how communication constitutes the school as an organization. Interestingly enough, this development is highly contingent, being influenced by the educational governance structure of the respective school system. Hence, we have to deal with two different cultures or social worlds within the school, which are mutually dependent but each constitutive of school in different ways: teaching and learning as well as administration and management.

Historically, schools have always been mediatized worlds. If we go back to the creation of the public school system in England, or the Prussian school system in Germany, media played an important role justifying or arguing for their foundation as well as in the pedagogical and administrative subsystems within any individual school. If we think about books, blackboards and chalk on the one hand and "pigeon holes" for teachers, log-books, or print-outs on the other hand, we can identify various forms of mediatized communication besides the dominant face-to-face communication between teachers and their students. Using Krotz's categorization of mediatized communicative processes, we can observe similar patterns in the two identified 
school worlds, which constitute the "media ensemble" (Morley, 2007, p. 200) of teachers and administrators (table 1).

Table 1: Communication in mediatized school worlds

\begin{tabular}{|c|c|c|}
\hline & Teaching and Learning & Administration and Management \\
\hline $\begin{array}{l}\text { Direct interpersonal } \\
\text { communication }\end{array}$ & $\begin{array}{l}\text { Negotiation of paper-based or } \\
\text { digital homework, email } \\
\text { communication between teachers } \\
\text { and students }\end{array}$ & $\begin{array}{l}\text { Discussion and sharing of learning } \\
\text { content, grades etc. (paper-based or } \\
\text { digital) among teachers, with } \\
\text { administration and management, email } \\
\text { communication with parents }\end{array}$ \\
\hline communication & $\begin{array}{l}\text { Content distribution e.g. via } \\
\text { textbooks, film presentation, } \\
\text { digital learning resources }\end{array}$ & $\begin{array}{l}\text { Teacher pigeon holes, bulletin boards, } \\
\text { school websites, school information } \\
\text { system }\end{array}$ \\
\hline $\begin{array}{l}\text { Interactive } \\
\text { communication }\end{array}$ & $\begin{array}{l}\text { Digital learning environments, } \\
\text { game-based learning }\end{array}$ & $\begin{array}{l}\text { School management information } \\
\text { systems, performance feedback systems }\end{array}$ \\
\hline
\end{tabular}

As a summary, we can identify different processes, in which media play an important role within a school, following Schulz's extension of mediatization theory (Schulz, 2004, 88-90). (1) Spatial and temporal extension of the scope of human communication by media technologies, e.g. by using software programs to support individual learning outside the regular school time. (2) Substitution or transformation of existing social processes by new media, e.g. the use of computer games for learning. (3) Amalgamation and parallelization of media practice with other social action, e.g. by using interactive whiteboards in traditional classroom settings and (4) accommodation of social change by the sheer existence of media in society, e.g. school-wide technology plans for curriculum integration. The four forms of communication are well suited to understanding the recent media change but do not 
acknowledge the potential of adding new forms of communication which have not been in place before. Especially in the school setting, we can identify this form as an addition, when ICT is used as learning tool in a way that is distinct from any previous pedagogical process using ICT (e.g. using simulation programs in science classes).

\section{Educational Governance and Transcultural Mediatization in Schools}

Especially in education, the dimension of culture (and its derived governance structure) has to be taken into account to understand the "moulding forces of the media" (Hepp, 2012a). Media can be regarded as spaces for judgments and reactions by teachers, unions, and politicians. Especially the emergence of "mainstream national media" in the UK has influenced the conversation about education (also Couldry, 2004). Couldry identifies two types of intersecting meta-capital: (a) the state as stipulator of educational policy and (b) the media as the arbiter of 'real facts' (Couldry, 2003). While Couldry's perspective of media capital in education is mainly focused on mass media and the construction of pedagogic authority, our emphasis is on educational media supporting individual and group learning processes and organizational media for collaboration with in schools and the specific role of the school to promote media literacy.

Taking into account the current popular discussions in Germany (originally derived from the Anglo-American discussion on school effectiveness, school improvement and school-based management) on educational governance (e.g. Altrichter, Brüsemeister, \& Wissinger, 2007), we introduce a three-tier framework model that resembles the well-established distinction in sociology between macro, meso and micro level (fig. 1).

Figure 1: Three-level model of educational governance 


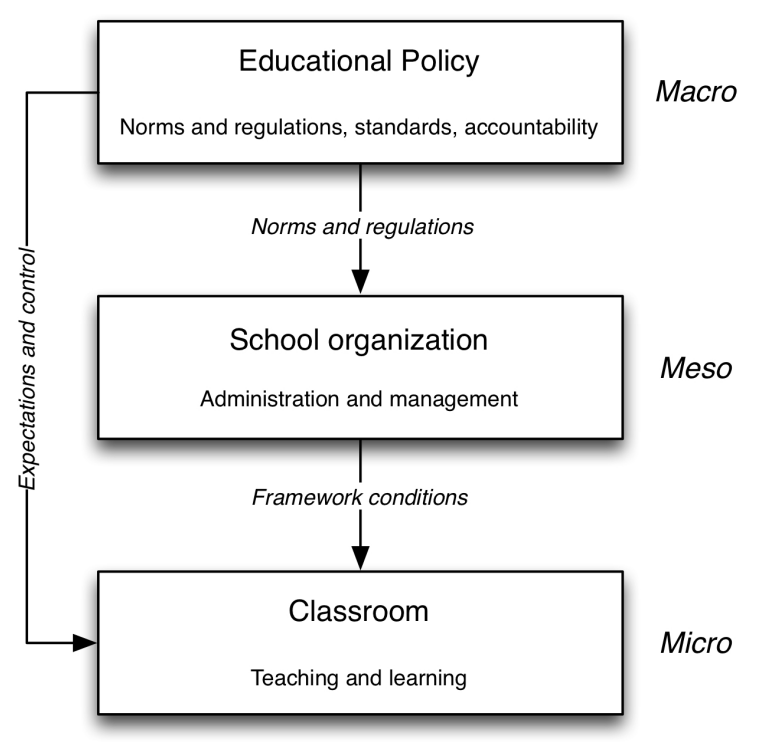

On the macro level, the relation between media change and educational policy can be mapped. On the micro level, the focus of mediatized communication is the teaching and learning processes in the classroom. The meso level draws specific interest on communicative action in relation to the school as an organization. In the following sections we provide examples of the three-level model and the interweaving processes using UK and Germany as references for very different school systems: The UK with a governance structure of centralized-decentralization and Germany as decentralized-centralization. As we regard the meso level as the intermediate layer that helps us to understand the ongoing interplay between the levels and emphasizing the process perspective, we re-ordered the typical micro-mesomacro structure.

\subsection{Micro Level: Media and the Classroom}

The current situation for teaching and learning with and about digital media is very different in the UK compared to Germany. There is an obvious difference between the use of media in the classroom on the one hand (media education) and the support of critical and reflective thinking about media and their role in society (media literacy). While the first is embedded into UK's National Curriculum and supported by large-scale equipment programs since the 
1990s (e.g. National Grid for Learning, DfEE, 1997), German teachers have no direct curriculum-based incentive to use ICT in their classroom and national and state-funded programs are rather rare. Hence, educational technologies are less prominent in German schools (student-computer ratio of 10 to 1), while UK schools rank among the most equipped of all OECD countries (student-computer ratio of 4 to 1, OECD, 2011). Furthermore, educational media such as interactive whiteboards can be found in nearly every UK classroom, while German schools are still struggling with budget and pedagogical around ICT in the classroom. Regarding the concept of media literacy, Livingstone and Van Couvering (2008) try to emphasize the continuities between old and new media and information and communication technologies by extending the term media literacy or literacy in general to encompass a converged concept of media and information literacies ${ }^{\text {ee }}$ (Livingstone \& Couvering, 2008). If we follow their argument, than technological advances lead to an increasing range of media contents which are available on computers, and hence, support and extend established ICT-literacy-related constructs rather than new technical and cognitive competencies. In this respect, the tradition in German classroom is different to the UK: Media literacy as a critical-reflective communicative practice has played an important role in Germany since the critique by Baacke (1973) and its extension within the media pedagogical discourse as Medienbildung, Medienerziehung and Medienpaedagogik (nota bene: only available in German, e.g. Baacke, 1997; Marotzki \& Jörissen, 2010).

The micro level has been addressed extensively in educational research with relation to ICT and learning. Mainly focused on the measurable impact of educational technologies on student learning outcomes, the empirical evidence is rather weak (e.g. Cuban, 2001; Hattie, 2009). For the UK, there are plenty of studies to explain the cause-and-effect relation between the provision of ICT and the impact on impact on education: more student-centered and constructivist, supporting higher-order learning and enhancing student's learning experiences and possibilities (e.g. Somekh, 2000; Selwyn, 2011; Yang 2012). 
In order to explain the specific situation in German schools, I will refer to our recent empirical study, which was conducted in 2010 among teachers in secondary schools in Germany's largest Federal State, North-Rhine-Westphalia (Breiter, Welling, \& Stolpmann, 2010). Based on a representative survey (1,500 teachers from 93 schools) and six case studies with qualitative interviews, the study aimed to understand the interdependence of the three levels of educational governance with regard to media literacy and the use of digital media for teaching and learning. Unlike other studies in Germany, we focus specifically on the role of the school as an organization and the accompanying framework conditions on the regional and policy level.

To summarize the results in order to reflect the process of mediatization in German secondary schools: More than half of the participating teachers use media at least occasionally (daily or once a week) in class. Teacher-centered classroom management by using laptop, presentation software and projector is still the dominant practice. This reflects the slowly changing patterns within schools and it demonstrates a high level of inertia, regardless of the ongoing media innovations outside the school and the media ensembles of both students and teachers. The use of media for teaching and learning is further limited by the enduring relevance of materiality in the learning process, which is still significant even though the use of digital media has advantages over existing practices. This reflects the unbroken popularity of traditional media like books. The data show an intergenerational gap of digital media use where teachers think "good" media for students are media for learning; "bad" media are media used in their leisure activities. The teachers' perception of students' use of media is often labeled with deficits. Further discrepancies are induced by the teachers' fundamental lack of understanding of many of the students' individual media practices outside school. With respect to media literacy, the beliefs of teachers are characterized by a strong focus on risks and dangers. In conclusion, we could find different dimensions of uncertainty and ambivalence. The ongoing, rapid evolution of digital media has an impact on everyday life in 
school and numerous forms of digital media have "forced" their way into school (e.g. Wikipedia, Interactive Whiteboards or Tablet-PCs). In this context, teachers retreat to wellestablished and familiar patterns is an attempt to maintain orientation and the capability to act and communicate within mediatized worlds.

\subsection{Macro Level: School Governance and Educational Policy}

Transnational pressures on changing education policy enforced by international nongovernmental organizations have been observed already by several scholars (e.g. Martens, Rusconi, \& Leuze, 2007). As Phillips (2011) pointed out, the UK education policy has historically observed the German education system in order to learn, adopt or reject this "role model". "There has been a consistent tendency over that long period [past hundred years, AB] to refer to the German example in education at one extreme to promote ideas for change and development ('do this and we shall be as successful as the Prussians') and at the other extreme to warn against innovation and reform ('do that you will end up as bad as the Prussians'), with various shades of attraction and repulsion in between” (Philips, 2011, p. 1). Philips researched various sources from travel documents of the $19^{\text {th }}$ century by English students and professors to studies by Her Majesty's Inspectors of Schools on the vocational school system in Germany in the 1980s to the discussions after PISA on educational measurement and its resulting performance tables.

The process of mediatization affects the teaching profession and the school system in a twofold way. Communicative processes change while digital technologies become more and more available. Educational reform is part of social change, which is inextricably connected with media change. Modern education policy is globalized due to transnational institutions such as the OECD (e.g. PISA) or the International Association for the Evaluation of Educational Achievement (IEA) (e.g. The International Mathematics and Science Study (TIMSS) or Progress in International Reading Literacy Study (PIRLS)). Their influence on 
education policy has changed significantly during the last decade (Martens et al., 2007). Nevertheless, the relation between UK and German education is of particular interest, as I argue that the "direction of indirect influence" has been reversed from Germany to the UK. Besides transcultural invariables deeply embedded into the culture of a school system and the values and beliefs of the teaching profession, we can observe culture specific adoptions of change, which can be observed first in the UK being later invisibly transported to Germany. Furthermore, the process of mediatization is enforcing this phenomenon (e.g. Lingard \& Rawolle, 2005).

As one outstanding example, the perspective on education in Germany changed tremendously from an input-oriented perspective to an output-orientation with metrics and indicators (Huber \& Gördel, 2006). Media served as amplifiers even more as digital media were available to distribute, interpret and re-analyze the data on student achievement. The huge gap between student achievements within Germany started an ongoing discussion about the quality of education, its measurability and the policy decision related with it. Especially the question about the best "school structure" dominated the public discussion. Most Federal States introduced central student achievement tests. Additionally, external evaluations and inspections were implemented and imposed on schools. Even more, the bad results from the PISA study in 2001 ("PISA shock") initiated a countrywide movement on collecting data from students, teachers and schools. Besides the official efforts, which often were consolidated into "education reports" on the State and Federal level, and into policy documents by researchers, grass-root activities were started using social networking sites. As external teacher and/or school evaluations not withstanding school rankings were unknown in Germany so far, the public availability of ratings of teacher performance by students and parents evoked a general legal and ethical discussion. Hence, the availability of digital media fell on a fruitful ground of social change. 
Compared to Germany, some processes happened approximately ten years earlier in the UK. In 1988, the UK government launched the Education Reform Act (e.g. Flude \& Hammer, 1990), aiming to change radically the governance structure of the school system from the control of local administration to the school embedded into a central accountability mechanism (e.g. Pierson, 1998). Within this framework, the availability of school-based data on accountability was crucial as all schools could be compared in League Tables, displaying the compliance with the then newly introduced state standards and observed by the inspectorate. Taking one step forward in the mediatization of the school governance, all schools were requested to deliver data in real-time and in a pre-defined quality which could only be done by computer-based school information systems.

Directly related to ICT on the macro level in the UK, the new coalition government in the UK decided to close Becta, the central body responsible for the government's ICT initiatives in schools. Consequently, as Yang (2012, p.107) states, "the abolition of Becta indicate a shift from the top-down, government-led effort to integrate ICT into education to a bottom-up approach driven by local needs." In Germany, there never was a central agency and the Federal States have different policies to support the provision of ICT in schools. The legal division between the State, being responsible for general education provision, curriculum, teacher education and teacher employment and the school district being responsible for school buildings, facility management and administration is unique in the world. This shared responsibility and the limited autonomy of the school and its management lead to constant budget struggles about the cost for ICT infrastructure and educational media (for more details Breiter, 2001). Traditionally, the strong central control with standards and accountability in the UK by the National Curriculum, and the assessment regime has a strong influence on how teachers are willing to use the potential of educational technologies. According to Yang (2012), the pedagogical standards defined in the curriculum-assessment regime have a significant impact on teachers' pedagogical practice. For Germany, no corresponding 
evidence can be found. Firstly, Federal Standards for the core subjects were firstly introduced in 2005 (KMK, 2005), and there is not much experience about their relevance. Secondly, the new Federal Standards do not contain any link to ICT skills or media literacy and thirdly, research shows that German teachers are rather reluctant to follow Federal or State Standards as they have no direct impact on their everyday teaching. In contrary in the UK, every Key Stage in the National Curriculum defines measurable goals for media literacy. Selwyn (2011) pointed towards another transcultural difference between the UK and Germany: the influence of interest groups and supra-national institutions that enforce the use of educational technologies. Embedded into his critical approach of the political economy of education, Selwyn (2011) uses several examples from interactive whiteboards to notebook initiatives to support his argument.

\subsection{Meso level: Schools as mediatized organizational worlds}

According to our research, the meso level of schools has been underestimated with regard to its role in the transformation process. Here, the perspective of mediatization has to be divided into two general streams: educational media and organizational media. Since the creation of the public school system, education was inextricably linked with media. In educational research, the teacher him/herself is often regarded as the most influential "medium" in the learning process of students. Besides this very general understanding of media, the school is still governed around books with deeply rooted values and orientations of teachers. For decades, this has not much changed with the advent of digital media like computers, learning management systems, interactive whiteboards or digital content. Apparently, we can observe significant transcultural differences in adoption and appropriation of ICT in German and UK schools (Kolo \& Breiter, 2009). In our understanding, the organizational culture of schools has a crucial impact on these differences. We base our findings on the empirical research

within the Priority Program "Mediatized Worlds" (see footnote 1) on two in-depth case 
studies in school with a methodological mix of participant observations, qualitative interviews and quantitative analyses of log files from school information systems (Breiter et al. 2011). Following Weick (1995), organizations can be considered as networks of actions based on their own distinctive cultures and subcultures, which in turn, are formative for their members. Thus, an organization involves processes of designing an order of action (“organizing"). He considers this process of organizing as the way, how people make sense through an ongoing communicative process of action, selection, and interpretation. Following him, organizations are neither static nor stable entities, but communicative negotiation processes are continuously taking place when processing ambiguities or attributing meaning. This shows that, organizations form their environment and their members act within a self-constructed organizational reality. The attribution of meaning in organizations takes place in loosely coupled systems where the individual members have a large scope of decision-making. In his early work, Weick (1976) described schools and universities as prototypical organizations of this type. The process of attribution of meaning can be explained by the characteristic of "enactment". It is the process in which people in organizations (re-)produce their environment by means of their communicative actions thus making perceptible what they think: „,.. when the action of saying makes it possible for people to then see what they think" (Weick, 1995, p. 20). Hence, daily practices play an important role and they become manifest in different, everyday life, partly ritualized ways as can be exemplified in schools: teachers meet before the start of class to talk and to have breakfast together, members of the school board are regularly present in the breaks to be available, and joint festivities shall promote staff cohesion in an informal way. Moreover, everyday life at school offers many opportunities of spontaneous and intended encounter and communication, e.g. joint meals in the canteen, incidental encounters in the building or formal meetings.

Based on Weick's basic assumptions, approaches to the communicative constitution of organizations have been developed further. Putnam and Nicotera (2010) ascribe 
communication a central role in the ontology of an organization (Putnam \& Nicotera, 2010). For this understanding, the interaction of the members is decisive: "A pattern or array of types of interaction constitute organizations insofar as they make organizations what they are, and insofar as basic features of the organization are implicated in the system of interaction“" (McPhee \& Zaug, 2009, p. 27). With this, McPhee and Zaug try a balancing act between the static understanding of an organization and a dynamic, constructive perspective, introducing four dimensions of the communicative constitution: membership negotiation, self-structuring, activity coordination and institutional positioning. In our empirical study in two large innercity schools (see footnote 1), we could identify the four dimensions being constitutive for schools (see Table 2).

Table 2: Four dimensions of schools as communicatively constituted organizations

\begin{tabular}{|l|l|}
\hline Membership & $\begin{array}{l}\text { Relationship between teachers and school, school-specific scripts, relevance } \\
\text { of school culture for the negotiation process (e.g. identification, belonging, } \\
\text { leadership) }\end{array}$ \\
\hline self- & $\begin{array}{l}\text { Communication between teachers, interactions guiding the school in a certain } \\
\text { direction, creation of arenas for negotiation (e.g. staff meetings, working } \\
\text { groups), with explicit and implicit rules }\end{array}$ \\
\hline Activity & $\begin{array}{l}\text { Interactive joint construction of working processes by teachers, students and } \\
\text { administrators, use of different instruments for coordination (e.g. curricula, } \\
\text { asset management, class roasters or pigeon holes) }\end{array}$ \\
\hline Institutional & $\begin{array}{l}\text { Development and creation of consistency of the school's external } \\
\text { positioning }\end{array}$ \\
\hline
\end{tabular}

Furthermore, media appropriation influences the communicative processes, particularly between staff and management. The media ensembles of teachers for communicative action 
are shaped by six factors (Breiter et al. 2011): (1) expected flow of communication, i.e. how fast and secure is the transport of the message; (2) range of the usable media ensemble (from paper-based to digital); (3) time and effort for mediated communication under the perspective of rationalization; (4) quality of communication in respect to the risk of misunderstanding between direct interpersonal and mediated communication; (5) binding power of communication, i.e. documentation of conversation with parents; and (6) lack of skills for using new forms of mediated communication accompanied with a high level of uncertainty among teachers.

As a hindering factor, our study could identify the role of the school's organizational culture for media integration. The results confirmed previous international research that the principal plays a central role for change processes in schools (e.g. Blumberg \& Greenfield, 1986; Day et al., 2000; Green, 2010). Our study revealed that there is a statistically significant increase in media use by teachers if the principal (and school management) has a pronounced interest in digital media and if the school's leadership is open to innovation. A similar positive statistical effect can be seen with regard to the teachers' assessment of the available technology infrastructure. Furthermore, the principal can initiate and consolidate cooperative structures among staff, which results in positive stimuli for media integration. Wherever the pedagogical objectives and goals for media integration are discussed within the school and are defined in a technology plan (for a cross-country comparison see Breiter, 2001), a positive correlation with the use of media is found. Schools and their leaders in Germany have a relatively limited autonomy compared to UK schools. Head teachers are mainly teachers and only secondarily managers. The process of mediatization has - to a certain extend - struggled and undermined this separation. Digital media cannot be differentiated between infrastructure (district) and learning applications (State). Hence, the schools are the place to link the two perspectives together. While school leadership has been an integral part of school research in the U.S. and the UK (Leithwood, 1994; Sergiovanni, 1996), it is relatively new in the German 
context and only available in German language (e.g. Wissinger, 2000). School-based management as the new governance model in the UK and the discussion in the U.S. is highlighting a new role of principals as "transformational leadership" (Leithwood, 1994) being the "agents of change" (Fullan, 2002).

In this context, mediatized communication becomes a central aspect of school development processes with school leaders being the main gatekeepers. They appropriate their own media ensembles while being forced to report to and inform their governing bodies, parents and local community. The organizational change due to educational reforms that are connected to issues of accountability, rankings and competition is increasing the pressure on schools. Here, we find an overlap between the pedagogical and the administrative realm of the school. Within the pedagogical realm, teachers are oscillating between school-level engagement and the interest group within the culture of their teaching subjects. Within the "administrative subculture" (Selwyn, 2011, p. 93f), Selwyn points towards new public management and, “... audit cultures of standardised content, assessment, official inspections and target-led performance" (ibid., p.93). Looking at the UK development, it is obvious that administrative processes were the target for pushing digital technologies in schools. Digital technologies “...offering an ideal means to help school organisations to become more flexible, adaptable and entrepreneurial in the business dealings." (ibid., p.19). In this transformation process, school leaders can be regarded as "mediatization agents". They establish and control power structures, have budget control and organize access to information systems and the mediatized communicative processes between school management and staff, parents and the local community. This highlights the overlapping, cross-level processes, which go beyond the traditional micro-meso-macro perspective. 


\section{Conclusion}

Given this, the understanding of schools as mediatized worlds provide us with a theoretical frame to observe organizational change in line with media change in a specific social world. Furthermore, the communicative construction of the school as an organization clarifies the interdependence between the social, the media and school reform, framed by politics, regional education authorities and by schools and their stakeholders. In the process of mediatization of education, as with other technological innovations, it has to be kept in mind that there is a constant struggle between social and technological determinism. Educators, especially, tend to believe in the next technological wave will solve pedagogical and organizational problems. “To avoid the threat of 'technological determinism', it is tempting to defend adamantly 'social determinism', which in turn becomes so extreme [...] that even the most open-minded engineer becomes a fierce technical determinist bumping the table with virile exclamations about the 'weight of material constraints'. These gestures have no other effect but to trigger even moderate sociologists to insist even more vehemently in the importance of some ‘discursive dimension'.” (Latour, 2005, pp. 144-145). Media are both technological and social and as such, new technologies are discovered in a process of research and development and “... set the conditions for social change and progress" (Williams, 1990, p. 13). On the other hand, technologies are a "... by-product of a social process that is otherwise determined" (ibid, p. 13).

Educational research has a longstanding tradition in examining teaching and learning processes, but the organizational world of schools is less prominent. Furthermore, books have been the constitutive medium for schools over generations embedded into a very stable socioeconomic system. If we take the ongoing process of mediatization in all social worlds, this will play an important role for educational change, enforced by organizational reform. In schools as mediatized worlds all four processes of Schulz's analytical framework can be found. With the presented examples, we identified both unique and shared patterns of 
transformation across the countries as well as across the micro, meso and macro levels. The limits of traditional approaches of understanding media, communication and organizational change in schools became obvious. There is no static description of change and, hence, communicative processes need to be captured by wider process models across the three levels for understanding social-cultural phenomena, such as Elias' concept of "figurations" (Elias, 1978). For Elias, figurations are "networks of individuals" (Elias 1978: 15) which constitute a larger social entity through reciprocal interaction - for example, by joining an organization such as a school or a classroom. The usefulness of this extension from the model of educational governance to a process model of educational change within mediatized worlds needs to be further developed.

\section{References}

Altrichter, H., Brüsemeister, T., \& Wissinger, J. (Eds.). (2007). Educational Governance. Handlungskoordination und Steuerung im Bildungssystem. Wiesbaden: VS Verlag. Baacke, D. (1973). Kommunikation und Kompetenz. München: Juventus.

Baacke, D. (1997). Medienpädagogik. Tübingen: Niemeyer.

Blumberg, A., \& Greenfield, W. (1986). The Effective Principal. Perspectives on School Leadership, 2nd Edition. Boston u.a.: Allyn \& Bacon.

Bourdieu, P., \& Passeron, J.-C. (1977). Reproduction in Education, Society and Culture. London: Sage.

Breiter, A. (2001). Digitale Medien im Schulsystem: Organisatorische Einbettung in Deutschland, den USA und Großbritannien. Zeitschrift für Erziehungswissenschaft, 4(4), 625-639.

Breiter, A., Welling, S., \& Schulz, A. H. (2011). Mediatisierung schulischer Organisationskulturen In A. Hepp \& F. Krotz (Eds.), Mediatisierte Welten: Beschreibungsansätze und Forschungsfelder (pp. 96-117). Wiesbaden: VS Verlag. 
Breiter, A., Welling, S., \& Stolpmann, B. E. (2010). Medienkompetenz in Schulen. Berlin: Vista.

Couldry, N. (2003). Media Meta-capital: Extending the Range of Bourdieu's Field Theory. Theory and Society, 32(5-6), 653-677.

Couldry, N. (2004). In the place of a common culture, what? Review of education, pedagogy and cultural studies, 26(1), 3-21.

Cuban, L. (2001). Oversold and underused: Computers in classrooms. Cambridge, MA: Harvard University Press.

Day, C., Harris, A., M., H., Tolley, H., \& Beresford, J. (2000). Leading Schools in Times of Change. Milton Keynes: Open University Press.

DfEE. (1997). Connecting the Learning Society: National Grid for Learning. The Government's Consultation Paper. London: Department for Education and Employment, H.M.S.O.

Elias, N. (1978). The History of Manners. The Civilizing Process. New York: Pantheon.

Flude, M., \& Hammer, M. (Eds.). (1990). The Education Reform Act 1988: its origins and implications. London: Falmer.

Fullan, M. G. (2002). The Change Leader. Educational Leadership, 59(8), 16-21.

Green, R. L. (2010). The four dimensions of principal leadership. A framework for leading 21 st century schools. Boston, MA: Allyn \& Bacon.

Hattie, J. A. C. (2009). Visible learning: a synthesis of over 800 meta-analyses relating to achievement. London: Routledge.

Hepp, A. (2012a). Mediatization and the 'Moulding Forces' of the Media. Communications, $37(1), 1-28$.

Hepp, A. (2012b). Cultures of Mediatization. Cambridge: Polity Press.

Hjarvard, S. (2012). Doing the Right Thing: Media and Communication Studies in a Mediatized World. Nordicom Review, 33(1), 27-34. 
Huber, S. G., \& Gördel, B. (2006). Quality Assurance in the German School System. European Educational Research Journal, 5(3), 196-209.

KMK. (2005). Bildungsstandards der Kultusministerkonferenz. Bonn: Sekretariat der Ständigen Konferenz der Kultusminister der Länder in der Bundesrepublik Deutschland.

Kolo, C., \& Breiter, A. (2009). An Integrative Model for the Dynamics of ICT-based Innovations in Education. Digital Culture \& Education, 1(2), 89-103.

Kozma, R. H. (Ed.). (2003). Technology, Innovation, and Educational Change. A Global Perspective. Washington, DC: ISTE.

Krotz, F. (2007). The meta-process of 'mediatization' as a conceptual frame. Global Media and Communication, 3(3), 256-260.

Krotz, F. (2009). Mediatization: a concept with which to grasp media and societal change. In K. Lundby (Ed.), Mediatization: Concept, Changes, Consequences (pp. 21-40). New York: Peter Lang.

Latour, B. (2005). Reassembling the Social - An Introduction to Actor-Network-Theory. Oxford: Oxford University Press.

Leithwood, K. (1994). Leadership for School Restructuring. Educational Administration Quarterly, 30(4), 498-518.

Lingard, B., \& Rawolle, S. (2005). Mediatising educational policy: The journalistic field, science policy and cross field effects. Journal of Education Policy, 10(3), 361-380.

Livingstone, S., \& Couvering, E. V. (2008). Converging traditions of research on media and information literacies. In J. Corio, M. Knobel, C. Lankshear \& D. Leu (Eds.), Handbook of Research on New Literacies (pp. 103-132). New York: Lawrence Erlbaum Associates.

Lundby, K. (Ed.). (2009). Mediatization: Concept, Changes, Consequences. New York: Peter Lang. 
Marotzki, W., \& Jörissen, B. (2010). Dimensionen strukturaler Medienbildung. In B. Herzig, D. Meister, H. Moser \& H. Niesyto (Eds.), Jahrbuch Medienpädagogik 8: Medienkompetenz und Web 2.0 (pp. 19-39). Wiesbaden: VS.

Martens, K., Rusconi, A., \& Leuze, K. (Eds.). (2007). New Arenas of Education Governance - The Impact of International Organizations and Markets on Educational Policymaking. Houndmills, Basingstoke: Palgrave Macmillan.

McPhee, R. D., \& Zaug, P. (2009). The Communicative Constitution of Organizations: A Framework for Explanation. In L. L. Putnam \& A. M. Nicotera (Eds.), Building Theories of Organization. The Constitutive Role of Communication (pp. 21-47). New York: Routledge.

Moores, S. (2012). Media, Place and Mobility. London: Palgrave Macmillan.

Morley, D. (2007). Media, Modernity and Technology: The Geography of the New. London: Routledge.

OECD. (2011). PISA 2009 Results: Students On Line. Digital Technologies and Performance (Volume VI). Paris: Organisation for Economic Cooperation and Development.

Pelgrum, W. J. (2001). Obstacles to the integration of ICT in education: results from a worldwide educational assessment. Computers \& Education, 37, 163-178.

Philips, D. (2011). The German Example. English Interest in Educational Provision in Germany Since 1800. London: Continuum.

Pierson, C. (1998). The new governance of education: the Conservatives and Education 19881997. Oxford Review of Education, 24(1), 131-142.

Putnam, L. L., \& Nicotera, A. M. (2010). Communicative constitution of organization is a question: Critical issues for addressing it. Management Communication Quarterly, 24(1), 158-165.

Schulz, W. (2004). Reconstructing Mediatization as an Analytical Concept. European Journal of Communication, 19, 87-101. 
Selwyn, N. (2011). Schools and Schooling in the Digital Age. London: Routledge.

Sergiovanni, T. J. (1996). Leadership for the Schoolhouse. San Francisco, CA: Josey-Bass.

Shibutani, T. (1955). Reference groups as perspectives. American Journal of Sociology, 60, $562-569$.

Somekh, B. (2000). New Technology and Learning: Policy and Practice in the UK, 19802000. Education and Information Technologies, 5(1), 19-37.

Visscher, A. J., Wild, P., Smith, D., \& Newton, L. (2003). Evaluation of the implementation, use and effects of a computerised management information system in English secondary schools. British Journal of Educational Technology, 34(3), 357-366.

Weick, K. E. (1976). Educational Organizations as Loosely Coupled Systems. Administrative Science Quarterly, 21, 1-19.

Weick, K. E. (1995). Sensemaking In Organizations. Thousand Oaks, CA: Sage.

Williams, R. (1990). Television, Technology and Cultural Form. London: Routledge.

Wissinger, J. (2000). Rolle und Aufgaben der Schulleitung bei der Qualitätssicherung und entwicklung von Schulen. Zeitschrift für Pädagogik, 46(6), 851-865.

Yang, H. (2012). ICT in English schools: transforming education? Technology, Pedagogy and Education, 21(1), 101-118. 